Jonathan Culpeper

Lancaster University

United Kingdom
2015, Vol. 12 (1), 137-139(144)

revije.ff.uni-lj.si/elope

doi: 10.4312/elope.12.1.137-139

\title{
Cultural Encounters: A Final Word
}

The notion of "culture" must surely stand as one of the most controversial, most difficult to define concepts in academia. Such are the problems that one is tempted to evade the concept altogether. And if one is brave enough to pursue the concept, there lingers the suspicion that the concept is fatally flawed. Consider, for example, Sarangi's $(2009,87)$ point, as noted in the introduction to this volume, that "any definition of culture is necessarily reductionist." That raises the issue of whether it is worthwhile pursing research that has such a reductionist category as culture at its heart. In fact, in my view any kind of research that involves analysis is - perhaps by definition - reductionist. Analysis involves reducing phenomena to analytical categories by identifying commonalities amongst them. Perhaps the point here is that culture as a category it particularly reductionist. However, even that rather depends on how one defines culture and operationalizes it. This is where it is particularly instructive to consider how the papers in this volume have handled this issue.

This volume is usefully organised into two sections. We have one section including cross-cultural papers "identifying individual cultural areas" and examining them in relation to each other, and another section including intercultural papers examining "borrowings of cultural elements across cultural groups and the way this exchange is evaluated." Yet the editors are careful to note that these two parts do not form a dichotomy, but a continuum. Gąsior's paper on "Cultural Scripts and the Speech Act of Opinions in Irish English: A Study amongst Irish and Polish University Students" begins the first section. Here, culture is operationalized in terms of "cultural scripts," as devised by, notably, Anna Wierzbicka and Cliff Goddard, who pioneered Natural Semantic Metalanguage, a means of describing cultural issues without culturally biased language but instead universal semantic primes. This approach had never particularly been to my taste, partly because the descriptions often seem to be vague paraphrase. However, Gąsior's paper proceeds with care, noting limitations (e.g. describing her study as a snapshot of the cultures and languages involved, rather than a definitive statement on the nations involved), and producing evidence for all parts of its claims about cultural scripts. That evidence is provided by role-plays and focus groups, methodologies that are perhaps not used as much in cross-cultural research as they should be. By the end of the paper the reader is convinced of her conclusion that there are differences between the expression of opinion in Irish English compared with Polish, with the Polish speakers gravitating rather more towards frankness.

Kavalir examines characteristics of the domain that can be labelled 'house and home' in the British Isles, North America, and Slovenia. She draws on Helen Spencer-Oatey's (2008, 3), who defines culture as: "a fuzzy set of basic assumptions and values, orientations to life, beliefs, policies, procedures and behavioural conventions that are shared by a group of people, and that influence (but do not determine) each member's behaviour and his/her interpretations of the 'meaning' of other people's behaviour" (Spencer-Oatey 2008, 3). Kavalir's paper is a useful reminder that much work on culture is rather narrowly focused on one focal issue, a specific speech act, for example. But, as Kavalir notes, "even seemingly banal details will often (but not necessarily always) be tied to other concepts and the system of values in the culture." A particular innovation of this paper is that it deploys corpus evidence, specifically collocates (words that regularly co-occur with the 
target word and lend it meaning), to display evidence of those details. The use of corpora and corpus methods in many areas of the social sciences and humanities has seen remarkable growth over the last 10 or so years.

The final two papers of the first section, by Cavalheiro and Matek, consider culture in the context of teaching and learning. Cavalheiro focusses on intercultural communicative competence in ELF communication. This paper has an important message, namely, that English native speaker culture should not be assumed always to hold sway across the board. Conducting qualitative analysis of transcribed spoken ELF interactions, she shows us that in real interactions misunderstanding and miscommunication are not as common as one might think, and, importantly, when they do happen they are not readily ascribable to the cultural background of the participants. Matek's focus is on the teaching of horror literature in the multicultural classroom, as indeed many classrooms are. This may seem an unlikely topic for cultural issues. However, taking a broad notion of culture (one that includes race, ethnicity, gender, religion, class and subcultures), she shows how the horror genre can help students to focus on universal commonalities rather than differences, a valuable learning outcome for the multicultural classroom.

Three of the four chapters constituting the second part of the volume have in common the fact that they investigate cultural phenomena represented in literary and cinematic texts. Duarte examines "road stories," and specifically the film The Darjeeling Limited (2007) by Wes Anderson. This chapter is well-placed to begin this second part, exposing, as road movies often do, striking interactions between cultures. The brothers travel through an "alien culture" and in the process are forced to adopt new perspectives on themselves and their original Indian culture. The theme of alien culture - the culture of the "us" vs. the culture of the "them" - is continued in the next chapter. Poljak Rehlicki investigates war literature, specifically, several American fiction and nonfiction novels from the Vietnam and the Iraq Wars, with the aim of finding out how and why American soldiers failed to understand the culture of their enemies. The answer seems to be that American soldiers are less able to understand the culture of the Other because of their own cultural baggage: "Americans still see war as a conflict of ideas (always presuming that their ideas are more enlightened that those of their enemies) and disregard the importance of culture."

The final two papers of the volume are superficially dissimilar. However, they are in fact united by their particular concern for the cultural reception and intercultural awareness. Stopar focuses on the national stereotypes of Americans in the context of foreign language teaching. He elicited the adjectives that Slovenian students would use to describe Americans. This research reveals some striking differences between how the Slovenian students perceive the Americans and how Americans perceive themselves as reported in various studies. These differences, the author points out, are not captured by materials in the foreign language classroom, which present cultures as if they can be equated with nations and as if they are constituted by a stable set of attributes. The instability in cultural meanings is explored further by Trupej in the context of translation, specifically of the 'negro' in John Steinbeck's Of Mice and Men. Importantly, this paper reminds us that culture has a historical dimension, exploring, as it does, differences in translation and reception between socialist and post-socialist Slovenia. The author observes rather greater "softening" of the racist discourse in the socialist era translation of Steinbeck's book compared with the post socialist translation. This, the author suggests, may be partly due to the fact that racist discourse did not sit comfortably in the cultural and ideological context of socialist Slovenia.

Overall, this volume demonstrates why the notion of culture is worth pursuing. Of course, it is nothing new to say that the notion of culture as simply a stable monolithic block is not tenable. 
But this volume does so much more than this. It displays the multiplicity of cultures, the sites of cultural interaction, the perceptions of cultures, and so on. Moreover, it also shows how in practical terms one might go about researching culture. A final point: if all this is sounding too complimentary, note that I am a member of the English cultures of England, and, if the stereotypes are to be believed, they are not particularly generous with their compliments!

\section{References}

Sarangi, Srikant. 2009. "Culture." In Culture and Language Use, edited by Gunter Senft, Jan-Ola Östman, and Jef Verschueren, 81-104. Amsterdam: John Benjamins.

Spencer-Oatey, Helen, ed. 2008. Culturally Speaking. Culture, Communication and Politeness Theory, 2nd ed. London: Continuum. 